\title{
Oridonin Sensitizes Hepatocellular Carcinoma to the Anticancer Effect of Sorafenib by Targeting the Akt Pathway [Corrigendum]
}

Li X, Chen W, Liu K, et al. Cancer Manag Res. 2020;12:8081-8091

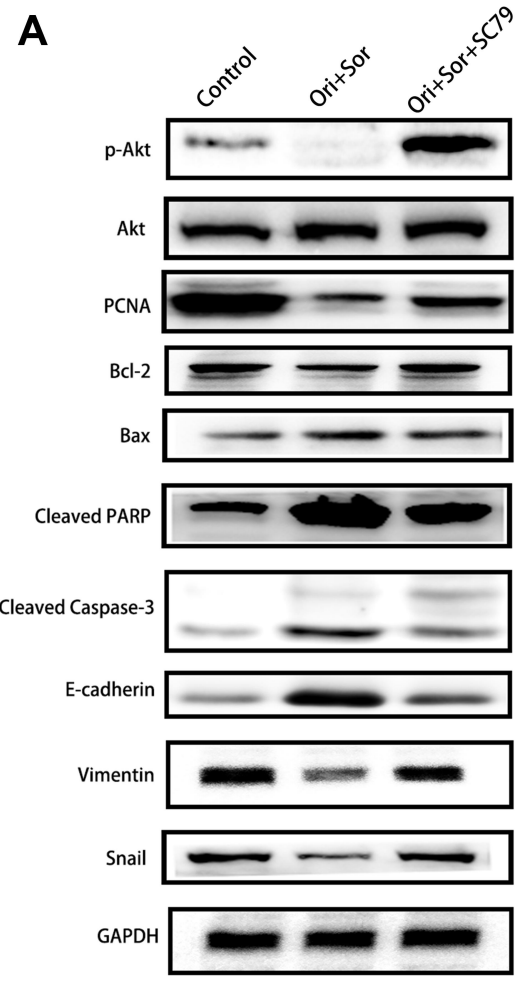

B

C

D

E
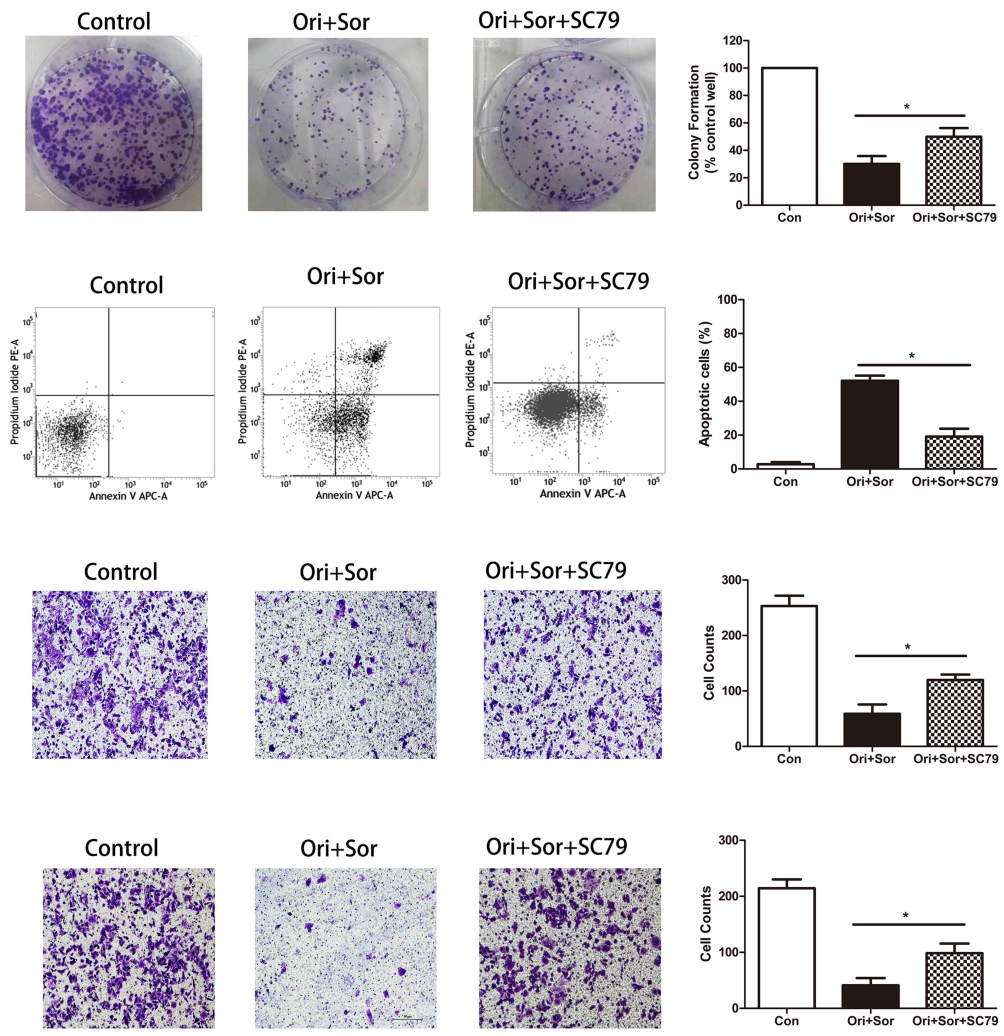

Figure 5 The Akt pathway played an important role in the anticancer effect of combined oridonin and sorafenib treatment. (A) SC79 was used to enhance the phosphorylation of Akt after cotreatment with oridonin and sorafenib, which partially restored the levels of proteins associated with proliferation, apoptosis and EMT. (B) Colony formation assays showed that SC79 treatment restored the proliferation that was inhibited by combined oridonin and sorafenib treatment. (C) Flow cytometry showed that the enhanced apoptosis induction caused by combined oridonin and sorafenib treatment was mitigated by SC79 treatment. (D and E) Reactivation of AKT after SC79 treatment restored cell migration and invasion that had been impaired by cotreatment with the two drugs. (The data represent the mean \pm SD of three independent experiments. *Indicates $p<0.05$ compared with the combination group; Ori + Sor indicates combined oridonin and sorafenib treatment).

\section{Publish your work in this journal}

Cancer Management and Research is an international, peer-reviewed open access journal focusing on cancer research and the optimal use of preventative and integrated treatment interventions to achieve improved outcomes, enhanced survival and quality of life for the cancer patient.
The manuscript management system is completely online and includes a very quick and fair peer-review system, which is all easy to use. Visit http://www.dovepress.com/testimonials.php to read real quotes

from published authors. 